\title{
ARCHAEOLOGICAL SITE - SACRED SPACE Popular religious beliefs and archaeological heritage in present-day Mongolia
}

Ganbold ByambaragchaA ${ }^{1}$ - József Laszlovszky ${ }^{2}$ - Zsolt SZiLÁGYi ${ }^{3}$

Hungarian Archaeology Vol. 9 (2020), Issue 3, pp. 33-42. doi: https://doi.org/10.36338/ha.2020.3.4

Archaeological sites are usually discussed as places of academic research, however, there is an ever growing demand for museums and archaeological parks that present reconstructed buildings and archaeological features in a form that makes them accessible for the wider public. Sometimes these monuments have strong connections to cultural tourism and education, and have the potential to be turned into an experience-based exhibition; in other cases they are strongly embedded in local religious phenomena, popular beliefs, or even have ties to one or the other of the major religious groups, making them sacred places. In this paper we discuss the sacralization process of archaeological sites in Mongolia. The examples examined below are partly connected to the Khi-Land project, a Hungarian-Mongolian landscape archaeological endeavour, and partly to the excavations in one of the largest Xiongnu sites, Noyon Uul (Noin-Ula).

\section{INTRODUCTION}

In today's Mongolia, as in other parts of the world, a rapid and spectacular modernization is apparent in almost all areas of culture. It is obvious, however, that the swift economic, political and cultural changes were followed by a sense of disappointment also in Mongolia. A typical reaction to the new conflicts created by globalization was a re-discovery of national traditions, with a special emphasis on the historical, cultural, and religious characteristics of the country. In Mongolia, the $20^{\text {th }}$ century was dominated by the socialist regime: the governments followed the Bolsheviks' example in persecuting all forms of Buddhist monastic culture - the latter had had a significant influence on the management of the country -, and spared no effort in destroying monasteries and the tangible and intangible cultural values accumulated in them. The regime change in 1990 brought unprecedented changes in the country; the most important element from this paper's point of view was the reintroduced freedom of religious observance. In the past 30 years, Mongolian Buddhism has been on the rise, but at the same time popular beliefs, shamanistic tradition, and other, proselytizing faiths have gained foothold in the country's everyday life. This religious revival has a deep impact on various aspects of cultural life; quite a few monasteries have been rebuilt, and Mongolian Buddhism is again recognized as a cornerstone of national identity. Lots of shamans and religious specialists are working again, and Tibetan Buddhist medicine as well as shamanistic healing rituals have claimed an expansive arena as alternatives to modern Western medical practices. Public education is, in certain areas, taken care of by the datsans, the traditional monastic schools. How shall we view these phenomena? Is there a chance for modernization to challenge the increasing dominance of religion and sacral traditions? Is it possible at all to achieve balance between the secular and the religious sphere?

\section{ARCHAEOLOGY AND SACRALITY IN PRESENT-DAY MONGOLIA}

Archaeological research examines its subject in a modern, often natural scientific context, while it focuses on areas and sites that are part of a people's historical and cultural traditions; it comes as no surprise that archaeological sites are likely places for these two conflicting points of view to become apparent. Archaeology, as a modern discipline, integrates these sites into its own contextual space, and by making them an object of scientific observation, archaeology changed the way these sites, burials, and one-time monasteries

\footnotetext{
Institute of History and Ethnology of the Mongolian Academy of Sciences. E-mail: byambaragchaag@mas.ac.mn

Central European University, Department of Medieval Studies, Cultural Heritage Studies Program. E-mail: 1aszlovj@,ceu.edu

Research Centre for the Humanities, Institute of Ethnology. E-mail: szilagyi.zsolt@,btk.mta.hu
} 
Ganbold Byambaragchaa - József Laszlovszky - Zsolt Szilágyi •Archaeological Site - Sacred Space

are interpreted and viewed. In an archaeological context, the site loses its sacrality, even in cases where the original function of the site was strictly religious. However, for the local community and the lamas and shamans representing it, these places remained sacred ground where religious rituals should be held, even if the space itself has become void of its old meaning due to archaeological excavations or other activities, such as mining projects.

The Inner Asian aspects of this phenomenon were first noted by a research team in the autumn 2016, during the Mongolian-Hungarian landscape archaeology project called Khi-Land. The project itself was based on a cooperation between archaeologists, landscape archaeologists, land surveyors, GIS specialists, as well as historians and religion experts, and so it obviously involved the study of modern ethnographic phenomena in connection with archaeological sites and research. In our previous reports we have written about circumstances that affected the possibilities of survey and fieldwork (CSIKY et al. 2017a; 2017b; Erdenebold et al. 2018; Harmath et al. 2018; Laszlovszky \& Szilágyi 2018; 2019; Tolnai et al. 2019). It became clear during fieldwork that elements of popular religion have strong ties to certain sites and archaeological monuments, and upon realizing this, we strove to collect and record these phenomena and contacted researchers who had already studied similar customs in modern-day Mongolia. Therefore, it is possible to cite other examples in this paper in addition to what we observed during the Khi-Land project. Ganbold Byambaragchaa from the Institute of History and Ethnography of the Mongolian Academy of Sciences, who has made research into similar ethnographic developments. has helped us immensely. His experience mainly concerns the archaeological site complex of Noyon Uul (Noin-ula), the largest archaeological assemblage of the Xiongnu Empire known in Mongolia to date. This site complex has gradually become a sacred space and is viewed as such by Buddhist lamas and Mongolian shamans alike; as a result, there has been an ever-growing conflict between the sacral and the secular perspective.

Only sporadic information is available on the novel, still changing and evolving religious practices around archaeological heritage. Although such phenomena have already sparked interest in the academic community, a detailed, comprehensive analysis is still to be done. In this paper we aim to discuss how certain archaeological sites became sacred spaces in Mongolia in the past few decades. The examples presented here reflect the two complementary views: while Noyol Uul is discussed G. Byambaragchaa mainly from the perspective of religion and religious social movements, the results of the Khi-Land project have a strongly landscape archaeological viewpoint, in which the elements of a historic landscape, the archaeological features, and the periods and layers of historical landscape use are examined. The latter viewpoint includes modern-day landscape use as well as contemporary religious and popular religious concepts about the landscape, just as a comprehensive analysis of Stonhenge must include the modern esoteric ideas around the site (Chippindale 1983). Such a complex analysis goes beyond the archaeological features themselves and their scholarly interpretation, and include the various concepts, non-academic theories, and rituals of the past and present around a given monument.

\section{THE PROFANE AND THE SACRED: SECULAR AND RELIGIOUS PERSPECTIVES}

In the last 20 years Mongolia has undergone a spectacular development in terms of GDP and economic growth, mostly due to mining projects aiming to exploit the country's vast mineral and precious metal resources. However, opencast mining takes its toll on the quality of air, water, and soil, causing serious environmental harm in the mines and in their surroundings. The excessive water use and the contamination of pastures pose a dire threat to nomads in these areas, whose livelihood is now in danger, as traditional nomadic husbandry often becomes unfeasible. It is no wonder that there is a growing resistance against such mining projects in Mongolia, and these movements sometimes have a religious aspect as well. The site complex of Noyon Uul, and the mining activities in its environment and the fight against it serves as a perfect example.

Similar attempts have been recorded in the Transbaikal region habited partly by a Mongolian (Buryat) population. Russian ethnographer Natalia Zhukovskaya reported that in support of anti-development move- 
Ganbold Byambaragchaa - József Laszlovszky - Zsolt Szilágyi •Archaeological Site - Sacred Space

ments, local shamans, Buddhist lamas, and other representatives of popular religion cooperated and organized religious rituals to protect a piece of land from a pipeline project by the Russian giant company, Yukos (ZhuKovsKaya 2009).

Sometimes, on the contrary, it is the members of the local community or religious actors who try to use development projects for their personal, often financial, gains. British anthropologist Mette High observed that lamas active around the Uryanga gold mines view the development project as a source of income rather than a danger to the local community. Drawing upon the traditions of the area, they organize "atoning rituals" in order to calm the spirits of the locality who, according to popular belief, must have adverse feelings towards the investment. Thus, the lamas contribute to maintaining calm in the local community. On the other hand, these rituals generate considerable income for them, which they fail to share with the community, even with its neediest members (HiGH 2013).

In his research, Shimamura Ippei (2014a) observed two extremes: there are religious people who take action against modernizing investments, and there are those who are in one way or another dependent on these development projects. His study of the gold and copper mine in Oyu tolgoi revealed that shamans held equivocal views on the mine; according to Shimamura, the shamans depended on the mine of Oyu tolgoi both in terms of their financial interests and the justification of their activities. They are on the one hand criticising the development projects, and on the other hand, they speak up for ecological investments.

The example cited by Shimamura differs from the nativist movements, such as the one in Buryatia. The shamans around Oyu Tolgoi, and the quasi traditional movements that pose themselves as authentic, are strongly dependent on the investment and the mining, as these constitute the object and cause of their rituals. He calls such movements "dependent resistance", the interests of which both coincide and conflict with the interests of the mine itself. In this sense, the religious and social movements around Noyon Uul also provide an example of dependent resistance, although they differ from the former cases because at Noyon Uul, shamans are reshaping the site into a sacred space.

\section{ANCIENT BURIAL PLACES AND THEIR MODERN SACRALIZATION: ELEMENTS OF POPULAR RELIGION}

Ancient burial places that are still perceptible in the Mongolian landscape and can be identified through observing surface phenomena, constitute another example of the role of popular beliefs. The so-called kheregsuur burials, that are still noticeable throughout the country and are marked on the surface by circles of stones, have never been disturbed by the local nomads, because they believe that underground objects should not be relocated or removed and disturbing them would be a bad omen (DELAPLACE 2015). Besides, disturbing the soil is a taboo not only from a religious perspective, but also in terms of the Mongolian nomads' traditional ecological knowledge. This was interpreted by some ethnographers as a shamanistic custom (SHIMAMURA 2014b). Tanaka Katsuhiko (2002) thinks that this taboo comes from the eco-philosophical perspective that Mongolians traditionally have of the environment, which considers environment preservation as a major goal. The majority of Mongolia's lands are unsuitable for agriculture, and ploughing the pastures causes serious damage from which the grazelands can barely recover (TANAKa 2002; SHIMAMURA 2014b).

The environment and natural resources of the Inner Asian steppe belt facilitated the development and maintenance of large-scale animal husbandry, which did not change considerably for centuries. There has been, however, a rapid shift in lifestyle in the past 50 years, although the traditional ecological knowledge of the Mongolians still emphasizes the need to protect pastures (GANTUYA et al. 2019). This contributed to the preservation of the burial places in the nomads' territories, as their beliefs kept them from opening the graves.

On the other hand, once a grave or site has been excavated and the finds have come to light, they become artifacts loaded with cultural meaning, which makes it possible to turn these excavated burial ground into a sacred place. The examples below concern the sacralization of Noyon Uul, and the religious practices we observed at the sites involved in the Khi-Land project. The examples are put in a chronological order, according to the periods the sites are associated with. 
Ganbold Byambaragchaa - József Laszlovszky - Zsolt Szilágyi • Archaeological Site - Sacred Space

\section{NOYON UUL}

The site of Noyon Uul (Fig. 1) is located in Selenge aimag (province) in northern Mongolia. There are approximately 200 kurgans, elite tumulus burials in the region, which probably date back to the period of the Xiongnu Empire, mainly in the 2nd-1st century BC. The site covers an area of ca. 129,6 ha in Kharaagiin Noyon Uul, and altogether 230 tumuli and burial places have been identified in the territory of three districts, called Bornuur, Mandal, and Töv aimag Batsümber sum.

The site of Noyon Uul was first described in 1912 by a geologist, Andrei Ballod, who identified the place as an important site of natural resources; he was working as an employee of a gold mine called Or around Noyon Uul. The archaeological heritage was first discovered by P. K. Kozlov from the Russian Geographic Society in 1923, when he started excavating in the area of the Xiongnu burials. Many of the artefacts recovered from here ended up in the Russian Ermitage Museum.

The burials of Noyon Uul were in the permafrost, and therefore, significant discoveries continued into the early 2000s, when textiles decorated with animal figures (supposedly from Persia), pieces of clothing of the elite, and Chinese ceramics were unearthed. It goes without saying that these findings are invaluable not only for the Mongolian scholarship, but also in an international context. After discovering the site, Kozlov started organizing a joint Russian-Mongolian research team, and proper excavations started in the mid-1920s. In the 1950s, Kh. Perlee and Ts. Dorjsuren conducted archaeological surveys here, and the latter became the first to publish a comprehensive summary about the sites of the Xiongnu, whom he called the "southern Huns". In the decades that followed, however, scholarly interest began to wane, and the site remained almost forgotten for a long time.

After the regime change in 1990, Mongolia's new international economic and academic ties paved the way to new endeavours. In the mid-2000s, research into mineral and precious metal resources started in the region as a Russian-Mongolian cooperation. Due to these surveys, excavations started in sectors Nos. 20 and 31 of Noyon Uul in 2006, which are in the vicinity of the Gatsuurt gold mine, located in a $8 \mathrm{~km}$ distance only. This mine is on the southern slope of the Noyon Uul mountain and covers the eastern part of the archaeological site. However, the terrain is so impassable that one needs to drive $100 \mathrm{~km}$ to reach the mine from the excavation site.

At the moment, the Gatsuurt mine is owned by a Canadian company, Centerra Gold Inc., which has been active in Mongolia since 2004. Preliminary surveys in 2013 reported that the area has 1.6 million ounces of gold. In January 2015, the Mongolian parliament declared the Gatsuur gold mine as a project of strategic importance.

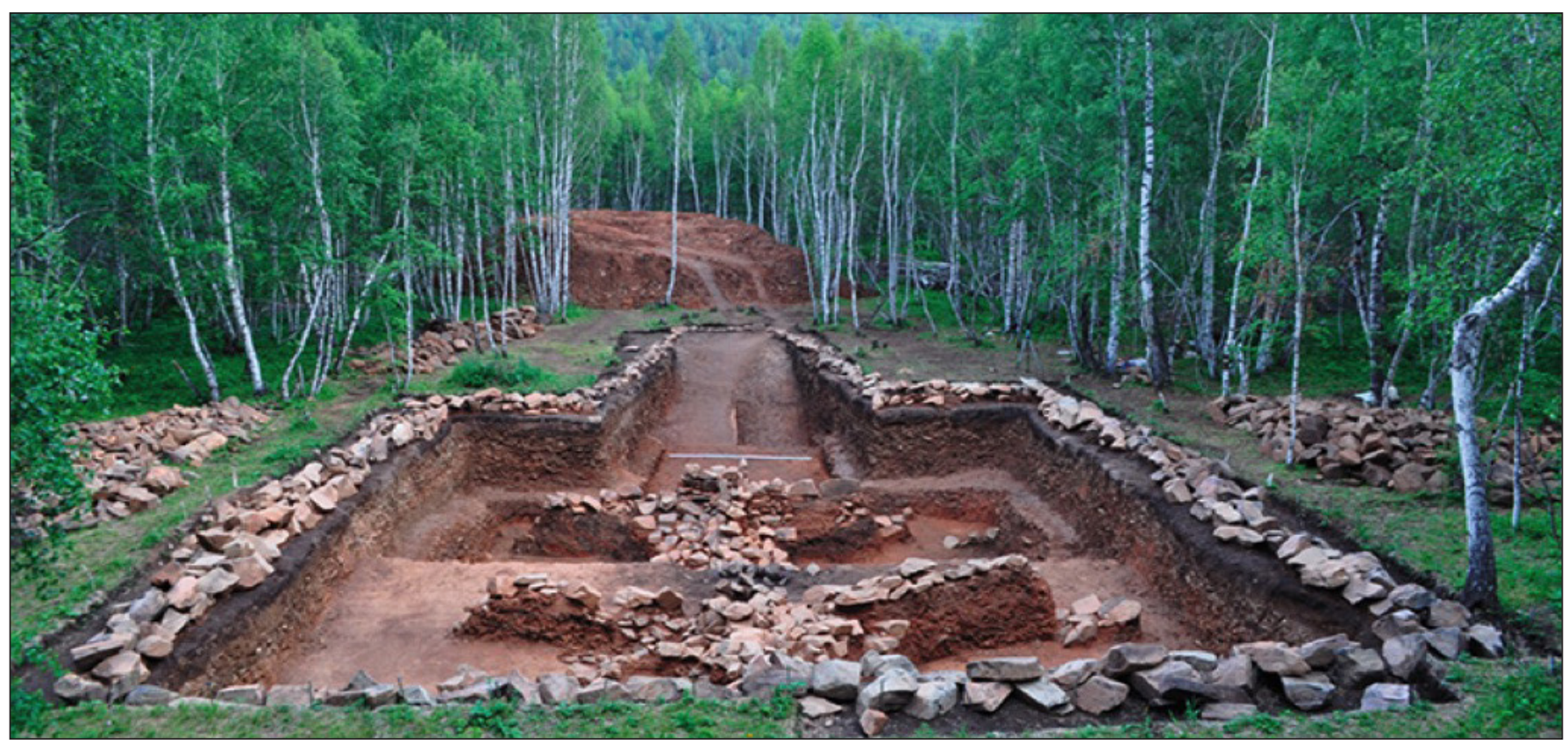

Fig. 1. An excavated section of the Noyon Uul site 
Ganbold Byambaragchaa - József Laszlovszky - Zsolt Szilágyi • Archaeological Site - Sacred Space

\section{RELIGIOUS ACTIVITIES AND THE SITE OF NOYON UUL}

According to the observations by G. Byambaragchaa, the inclusion of archaeological sites into sacral traditions is mainly due to the increasing influence of shamanic activities, which is based on the transformation of shaman traditions and popular religion in present-day Mongolia. The activity of shamans around Noyon Uul is a spectacular example.

On 9 February 2015, on the main square of the Mongolian capital Ulaanbataar, called Genghis Khan Square (formerly Sükhbaatar Square, in front of the Mongolian Parliament building), 40 shamans performed a common ritual for the sake of Noyon Uul (Fig. 2). The ritual was organized by NGOs, called the Bosoo Khökh Mongol, the Gal Undesten, and the Association of Mongolian Shamans. Byambaragchaa's informant (a 51 year-old udgan, female shaman, who went by the name Ts.) said that the ritual aimed to protect Noyon Uul, because her spirit helpers told her that ca. 100 people will die in accidents if mining will start in the area.

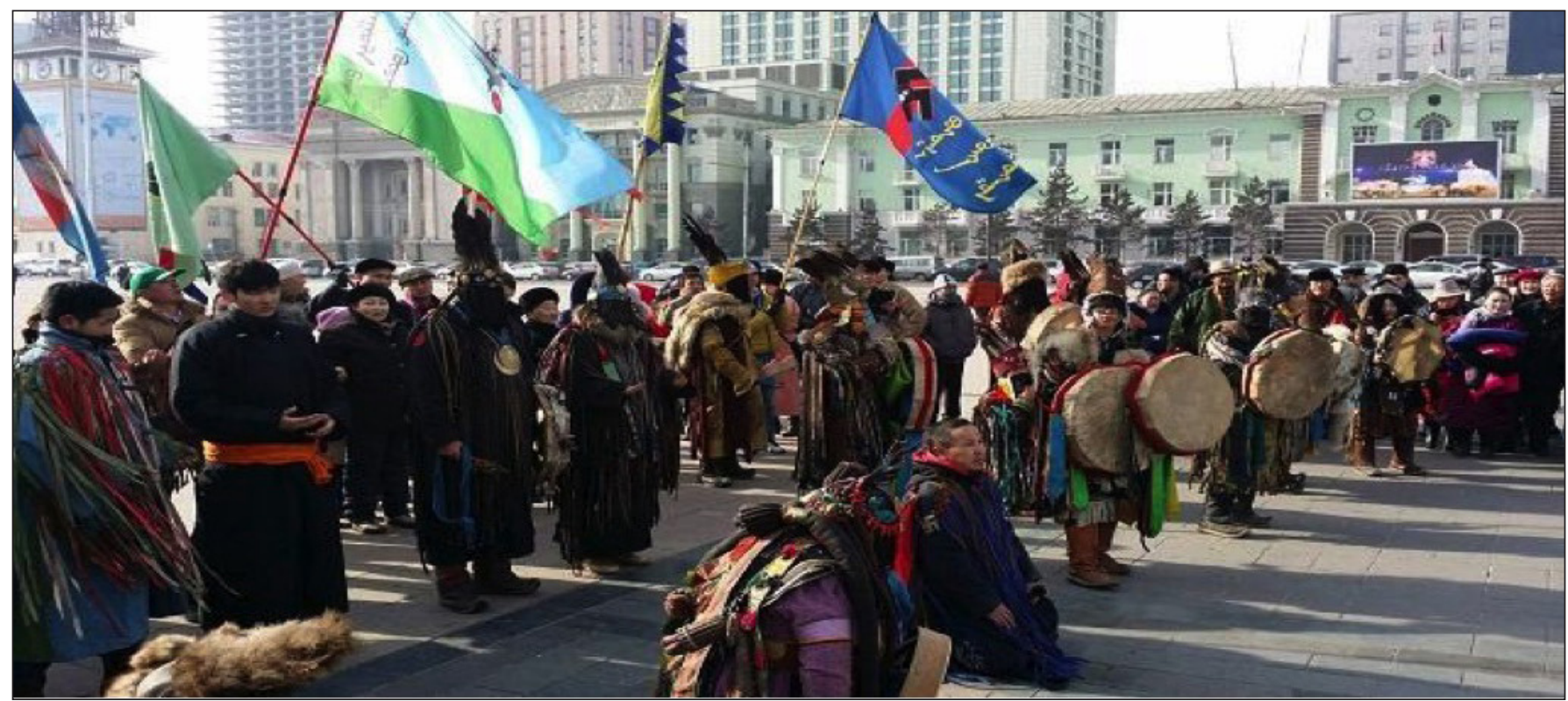

Fig. 2. Shamanic ritual for Noyon Uul on the main square of Ulaanbaatar

Even before that, in June 2012, 300 shamans gathered and performed a ritual near the tumuli in the northern part of Noyon Uul, Mandal sum district of Selenge aimag. The informant on that event, abbreviated as Sh., a 40 year-old male shaman (zairan), participated in the ritual and said that "this mountain is the holiest place in Mongolia, full of historical and cultural heritage, monuments, kurgans associated with the Xiongnu, the first Mongol dynasty (!). A lot of Xiongnu burials, both those of the elite and of ordinary
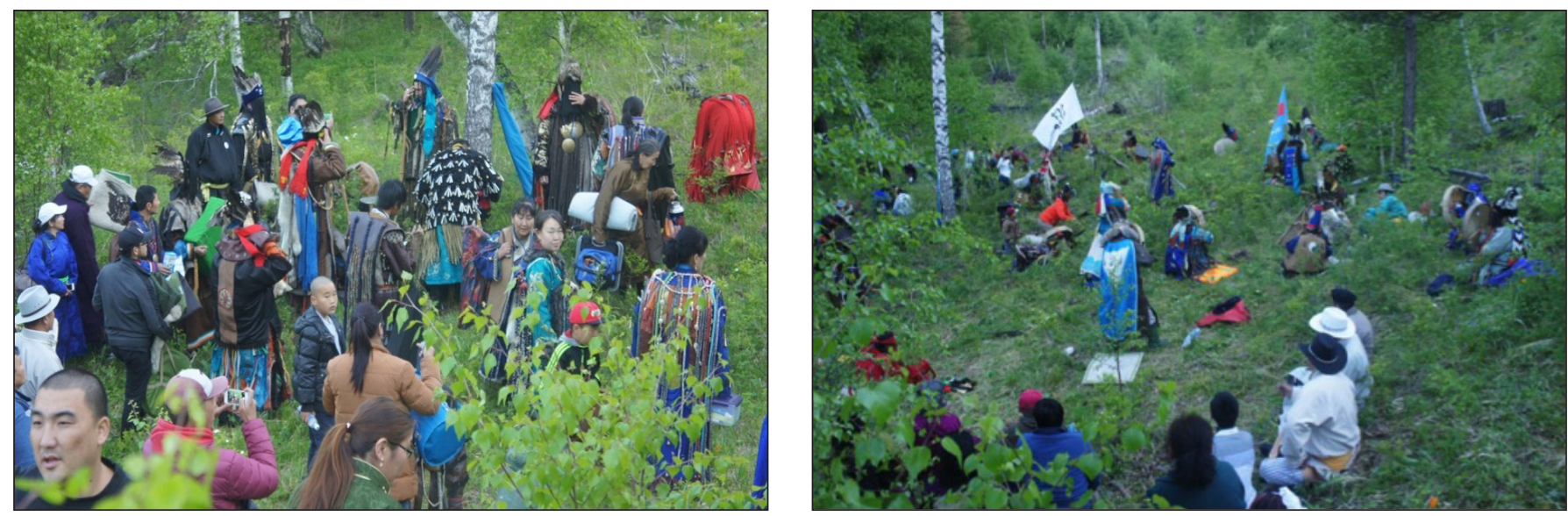

Fig. 3. Ritual on the Noyon Uul mountain 
Ganbold Byambaragchaa - József Laszlovszky - Zsolt Szilágyi • Archaeological Site - Sacred Space

people, are located here, and therefore we must protect this piece of land. Foreign investors seek their own financial gains and are interested only in the money, not in the cultural heritage."

On 13 June 2015, G. Byambaragchaa joined 25 shamans and 4 Buddhist lamas in the Mandal sum district of Selenge aimag, in performing a joint ritual for Noyon Uul (Fig. 3). This ritual was again organized by NGOs, the Bosoo Khökh Mongol, The House of Light, the Save Noyon Uul, and the Mongolian Democratic Union. The informant under the name G., a 58 year-old male shaman, said that "there are ancient Mongolian burials on this mountain, which means that this mountain is sacred for Mongolians. In the past few years, however, mining companies started exploiting the natural and cultural resources, especially here around Noyon Uul. Therefore, we pray for the mountain and ask the spirits who dwell here for their help."

The above examples show that Mongolian shamans and, indirectly, the revival of their traditions in the past 30 years (BALOGH 2010), have had a pivotal role in transforming the archaeological sites into sacred spaces and re-interpreting them as holy ground.

\section{FORTIFIED SETTLEMENTS AS PLACES OF THE REVIVING POPULAR RELIGION}

In the spiritual tradition of Mongolia, places of significance, natural phenomena, mountains, watercourses all had their own spirits and were, to one degree or another, sacred; thus these elements of the landscape constitute an important part of the religious practices (BIRTALAN 2004). In the past few years, the worship of archaeological sites appeared as a new element, although it is clear that it is not the archaeological discovery itself, but their role in the historical and cultural heritage what makes these places sacred. Ritual activities connected to the sites often appear in a non-organized form. The space itself, the valuable artefacts found there and their connection to a period of Mongolian history gives enough reason for

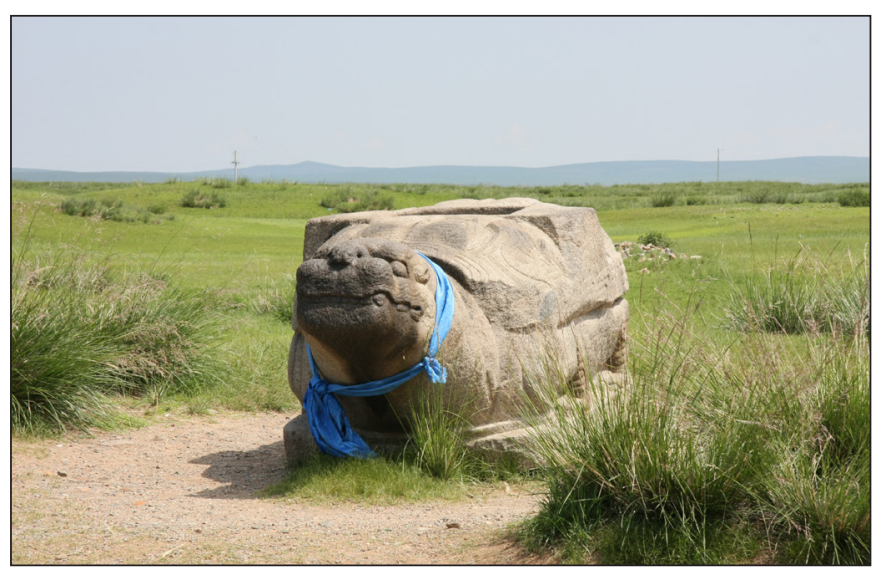

Fig. 4. Stone turtle with a sacrificial silk ribbon, next to the monastery of Erdene Zuu the visitors to commemorate their ancestors. A simple and widely known example is that the stone turtle in Karakorum (present-day Kharkhorin) is regularly ornamented with a silk ribbon, a khadag, as a form of ancestor worship (Fig. 4). The monastery of Erdene $\mathrm{Zuu}$, where the stone turtle stands, is a major site for Mongolian Buddhism and a pilgrimage centre for Buddhists of the country. Guests and pilgrims frequently visit the turtle, and sometimes a small sacrificial mound, an ovoo is built next to it. Although these mounds are usually removed, visitors keep rebuilding them, which means that the place serves as a kind of sacrificial space venerating the local spirit and the ancestors, similarly to another sacrificial mound in the vicinity, located in a current excavation area.

\section{KHAR BUKH BALGAS}

This Khitan period fortified settlement and the ruins of the 16th-17th century Buddhist monastery built in its territory, which stood in the focus of the Khi-Land project, also serve as an example for archaeological sites being turned into sacred spaces. As opposed to the previous examples, the activities in Khar Bukh Balgas are unequivocally connected to Buddhist revival. Previous excavations conducted in the ruined monastery of the one-time Khitan fort (Figs 5-6) brought to light a series of important findings in connection with early Mongolian Buddhism. Manuscripts and wooden tablets discovered next to the stupas erected in the main building and outside the town wall testify to the central role of Khar Bukh Balgas in early Mongolian Buddhism, as the finds here connect the place to the religious tradition in central and southern Mongolia (CHIODO 2000).

These discoveries themselves were enough to turn the monastery ruins and the stupa into a destination of pilgrimage. This is clearly shown by the khadags and other offerings put on display at the main entrance and 
Ganbold Byambaragchaa - József Laszlovszky - Zsolt Szilágyi • Archaeological Site - Sacred Space

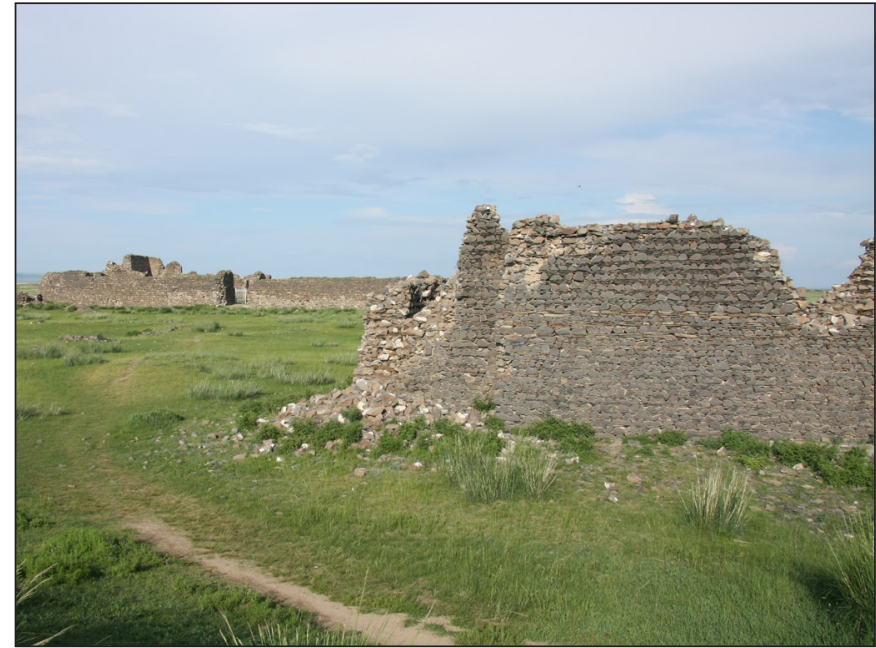

Fig. 5. The ruins of Khar Bukh Balgas

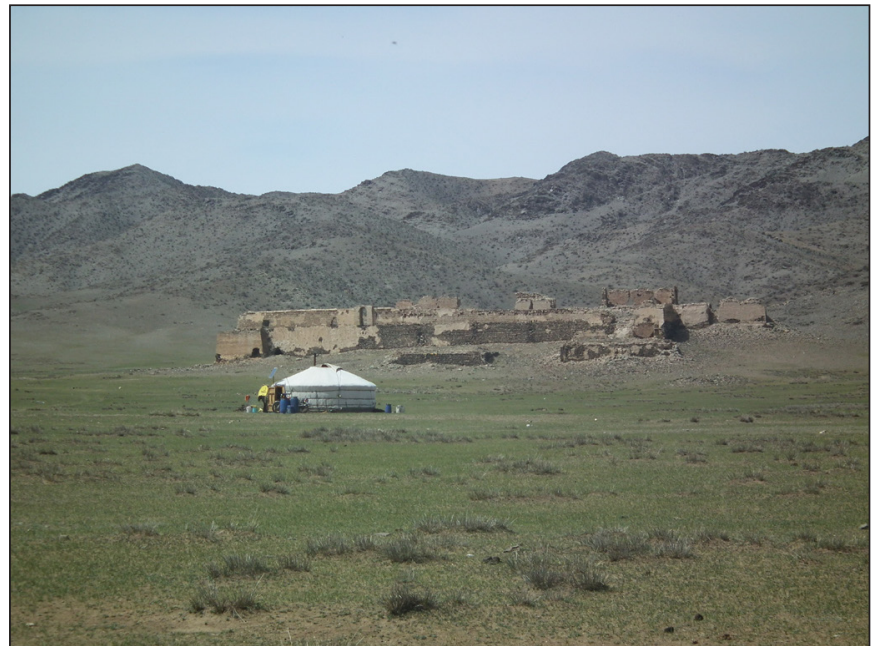

Fig 6. The White Palace (Tsagaan baishin)

inside the stupa (Figs 7-8). The participants of the Khi-Land project noticed during fieldwork that Mongolians frequently visit the ruins, and make offering here, as well as at another site, the so-called White Palace (Tsagaan baishin), ca. $30 \mathrm{~km}$ away from Khar Bukh Balgas, that the Khalkha-Mongol nobleman Tsogt taij (1581-1637) had built between 1601-1616 (LasZlovszky \& SzILÁGYi 2018) (Fig. 9).

Khar Bukh Balgas was not the only one among the archaeological sites investigated by the Khi-Land project (Csiky et al. 2017a, ERdEnebold et al. 2018, Tolnai et al. 2019) where such phenomena were

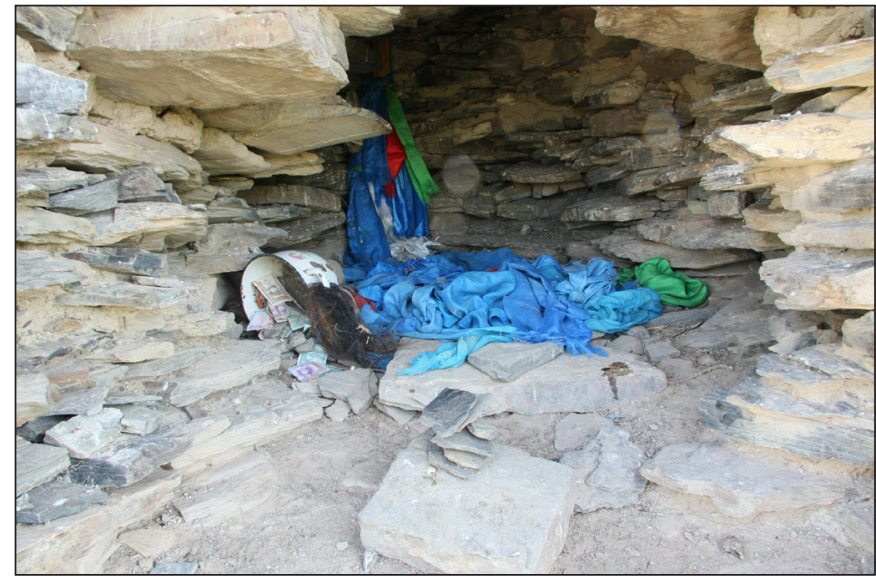

Fig. 7. Sacrificial ribbons and other offerings among the ruins of Khar Bukh Balgas

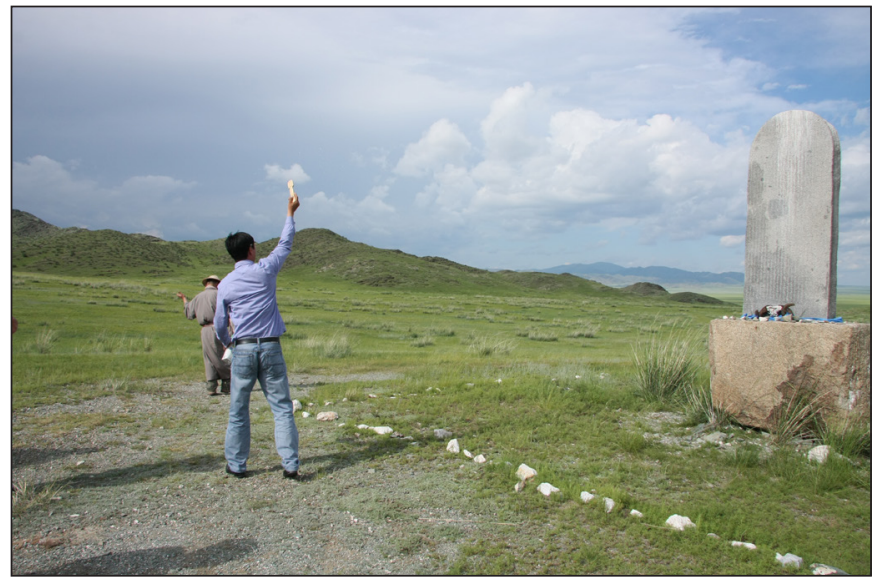

Fig. 9. Milk offering at the ruins of the White Palace (Tsagaan baishin)

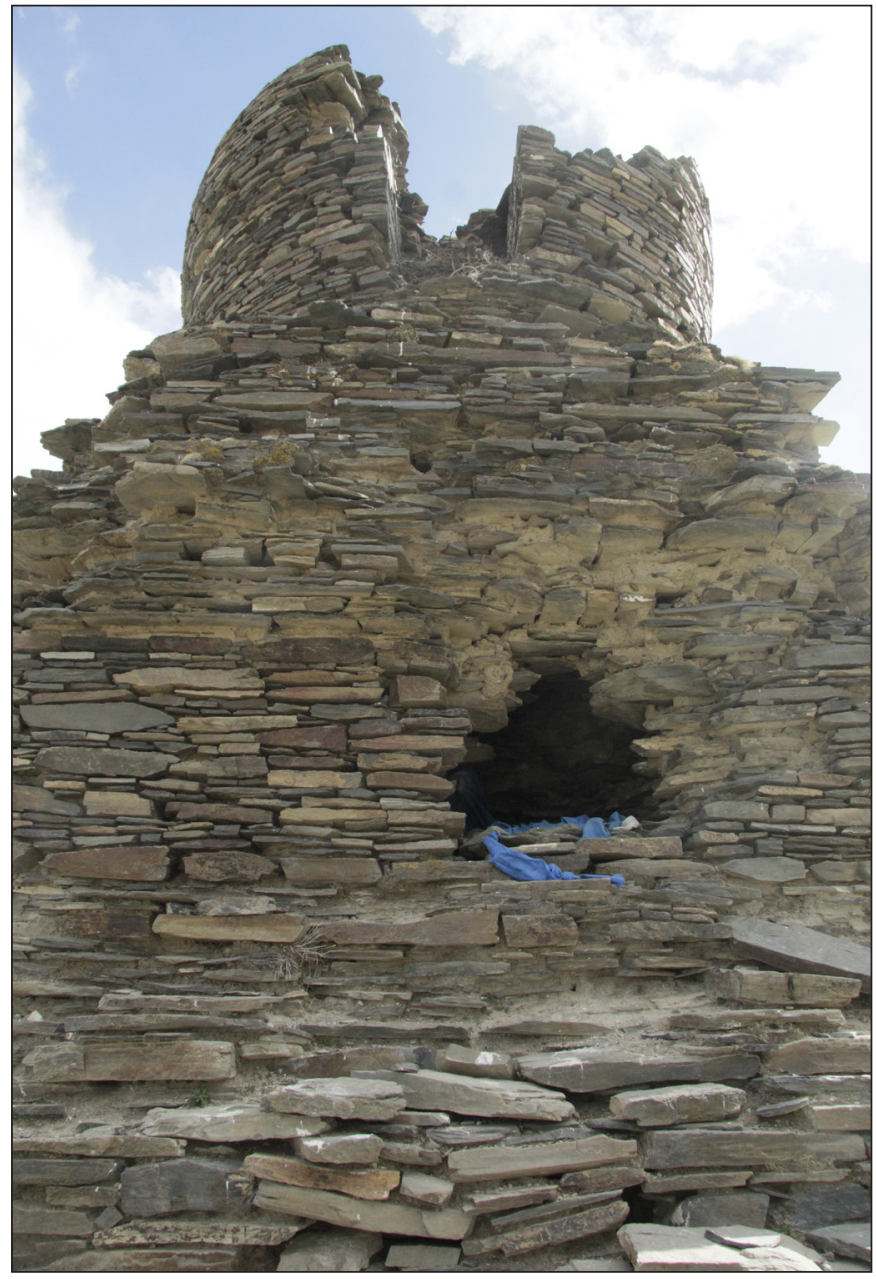

Fig. 8. Sacrificial ribbons and other offerings among the ruins of Khar Bukh Balgas 


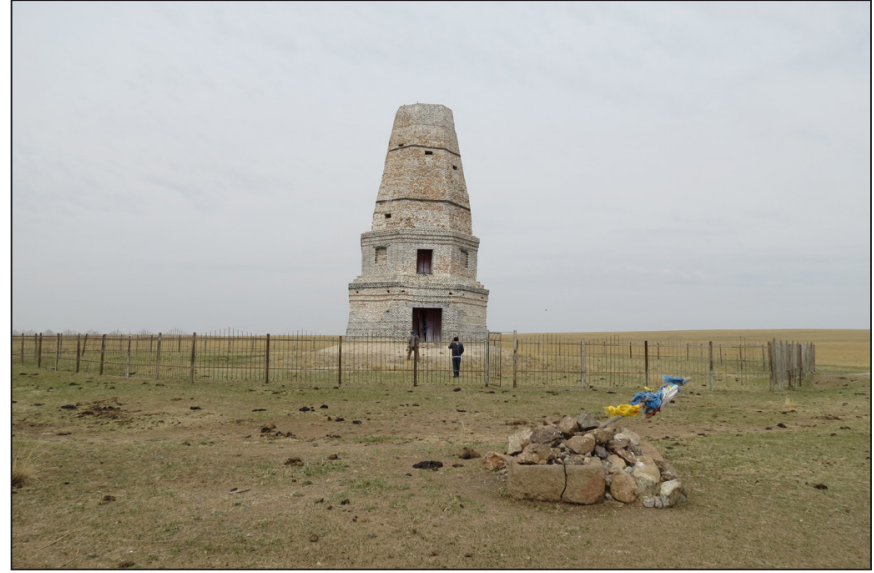

Fig. 10. Stupa near to Kherlen Bars khot

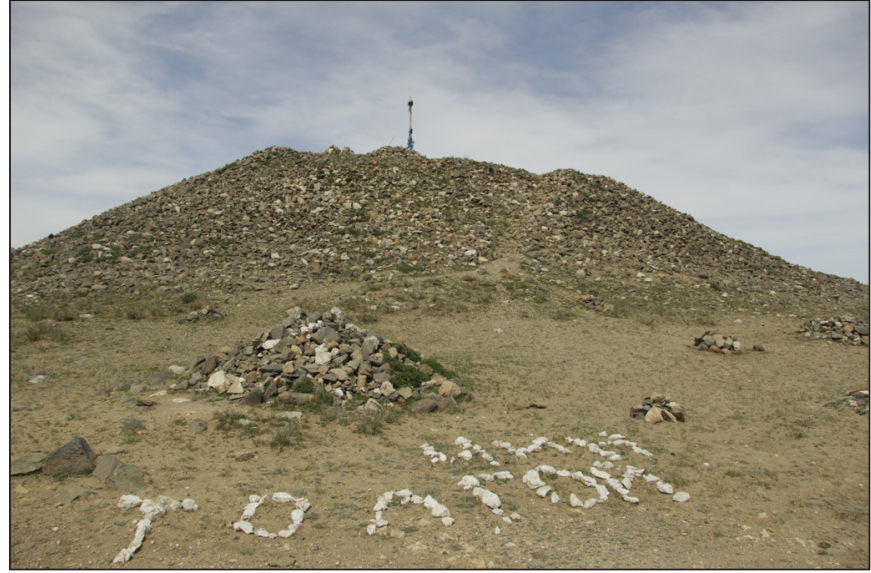

Fig. 11. Sacrificial ribbons and heaps of stones near Chin tolgoi

encountered. At Kherlen Bars khot in eastern Mongolia, religious activities were also observed (Fig. 10). Similar practices were seen at the Khitan-period site of Chin Tolgoi near Khar Bukh, although these were connected rather with local shaman traditions than Buddhism (Fig. 11). In these cases, several layers of religious activities can be reconstructed. These sites are primarily known as destroyed nomadic cities, which must have had areas dedicated to religious worship. After the Khitan period, some of these forts were repopulated (e.g. in the Mongol period), and new religious monuments must have been erected and rituals practiced. Later, the depopulated and ruined buildings were used by Buddhist monks who settled here; although, only a small part of these fortified settlements were revived and reused in this phase, these new religious communities have sometimes remained in these places up to the 20th century. Khar Bukh Balgas has a similar story: here, a Buddhist monastery was founded at the turn of the 16th-17th centuries, in the place of a one-time Khitan settlement. More recently, various groups of the present-day Mongolian society have chosen these sites, now predominantly interpreted as archaeological monuments, as places of worship.

The examples cited here, in which objects are deposited and offerings are made for a religious purpose at archaeological sites, serve as further evidence for religious syncretism in today's Mongolia. The worshippers, but often also the shamans and lamas themselves, use a mixture of elements from the Mongolian proto-religion, the shamanic traditions, and Buddhism during the rituals.

\section{CONCLUSION}

As a result of conflicts caused by globalization and modernization, in the past few years and decades the national, cultural characteristics gained a special emphasis in Mongolia, not only in everyday life but also in terms of diplomatic activities and the state's official communication and politics of memory. The cultural traditions, the Mongol proto-religion, and the shamanic rituals became a cornerstone of national identity beside Genghis Khan, but the same is true for Buddhism, which has been the official religion of the country from the 17th century onwards (SZILÁGYi 2016).

At the same time, actors of the political and academic life even more often refer to the Xiongnu Empire, the earliest known nomadic state in the area, as the predecessors of Mongolians. In these arguments, the importance of nomadic practices is again emphasized, and there is a non-negligible emotional element in this matter, which often casts a shadow on scholarly discourse, too. Thus, it is easy to understand why the largest Xiongnu site known to date in the country, Noyon Uul, is in the focus of debates that are, at times, far from academic.

However, there is no doubt that archaeological expeditions catalyse these phenomena. As it was mentioned earlier, these sites start stimulating huge interest only when significant findings are brought to light. This way, the artefacts and the heritage conveyed by them becomes tangible, accessible, and they become "available treasures" for the Mongolians - not necessarily in a financial, but rather in a cultural sense. These "treasures" are visible, touchable, and as such, the taboo that prohibits the opening of graves does 
Ganbold Byambaragchaa - József Laszlovszky - Zsolt Szilágyi •Archaeological Site - Sacred Space

not apply to them anymore (Delaplace 2015). In fact, the Mongolian concept of "treasure" and "resource" have almost the same meaning.

Sacrificial rituals play a pivotal role in shaping the sacred space. The offerings transform the mundane, secular space into a religious one, thus creating a link between the sacred and the profane, as it has been described by anthropologists (BELL 1997).

Of course, more research is needed for a proper interpretation of these phenomena; however, the Mongolian examples cited in this short study, as well as similar practices observed at archaeological sites in other parts of the world, provide evidence that a revival of traditional culture and ancient religious practices is a possible answer to the crisis of globalization and modernization. At significant archaeological sites in Mongolia, such as Noyon Uul, the old Khitan fortified settlements, especially Khar Bukh Balgas, or the ruins of the country's 13th-century capital, certain sacral activities, ancestor worship, and offerings made to the local spirits were observed. This means that these places have a meaning beyond their historical and cultural value and have become sacred spaces for the reviving Mongolian popular religious practices.

Among the examples cited above, Noyon Uul has been sacralised as a result of shamans' activities, while in Khar Bukh Balgas, it was the renaissance of Mongol Buddhism that facilitated this transformation. Although the site is viewed by modern scholarship as an archaeological site, the shamans, the Buddhist lamas and the worshippers see it as holy ground. The area excavated by modern research has become a place where profane and sacral perspectives are entangled, providing a spectacular evidence of the complexities and the possibilities of interpretation for historical landscapes and multi-layered archaeological sites.

\section{BIBLIOGRAPHY AND RECOMMENDED LITERATURE}

Balogh, M. (2010). Contemporary Shamanism in Mongolia. Asian Ethnicity 11 (2010), 229-238. http:// dx.doi.org/10.1080/14631361003779489

Bell, C. (1997). Rituals: Perspectives and Dimensions. New York: Oxford University Press.

Birtalan, Á. (ed.) (2004). Helyszellemek kultusza Mongóliában [The cult of local spirits in Mongolia]. Budapest: Új Mandátum Kiadó.

Chiodo, E. (2000). The Mongolian Manuscripts on Birch Bark from Xarbuxyn Balgas in the Collection of Mongolian Academy of Sciences. Wiesbaden: Harrassowitz.

Chippindale, C. (1983). Stonehenge Complete. London: Thames and Hudson.

Csiky et al. (2017a). Csiky, G., Erdenebold, Lkh., Harmath, A., Jambajantsan, A. D., Szilágyi, Zs. \& Tolnai, K. (2017). The Khi-Land Project: An Archaeological Programme and Research in the Area of Khar Bukh Balgas, Mongolia. Hungarian Archaeology 6/2 [2017 Summer], 1-8. http://files.archaeolingua. hu/2017NY/Csiky-Tolnai\%20E17NY.pdf (Last accessed: 4 November 2020.)

Csiky et al. (2017b) Csiky, G., Erdenebold, Lkh., Harmath, A., Jambajantsan, A. D., Szilágyi, Zs. \& Tolnai, K. (2017) Khi-Land projekt. Mongol-magyar régészeti kutatások [The Khil-Land project. MongolianHungarian archaeological research]. Budapest: MTA Bölcsészettudományi Kutatóközpont.

Delaplace, G. (2015). An open-air treasure in Mongolia short history of the uranium mining town of Mardai. Sôgentokôseki. Mongoru, Chibetto ni okerushi gen kai hatsuto kankyô mondai. In Tanase, J. \& Shimamura, I. (eds.), Steppe and Mine. Natural Resource Development and Environmental Problems in Mongolia and Tibet (pp. 39-52). Tokyo: Akashi Shoten. 
Ganbold Byambaragchaa - József Laszlovszky - Zsolt Szilágyi •Archaeological Site - Sacred Space

Gantuya, B., Avar, Á., Babai, D., Molnár, Á. \& Molnár, Zs. (2019). “A herder's duty is to think”: landscape partitioning and folkhabitats of Mongolian herders in a mountain forest steppe (Khuvsugul-Moron region). Journal of Ethnobiology and Ethnomedicine 15 (2019), Article No. 54, 15-54. https://doi.org/10.1186/ s13002-019-0328-X

Harmath, A., Laszlovszky, J., Siklódi, Cs., Szilágyi, Zs. \& Tolnai, K. (2018). A lovasnomádok mongóliai erődítményei nyomában [On the fortresses of equestrian nomads in Mongolia]. Várak, kastélyok, templomok. Évkönyv 2018, 62-66.

High, M. (2013). Cosmologies of freedom and Buddhist self-transformation in the Mongolian goldrush. Journal of the Royal Anthropological Institute 4 (2013), 753-770. https://doi.org/10.1111/1467-9655.12063

Erdenebold, Lkh., Tolnai, K., Harmath, A., Siklódi, Cs., Szilágyi, Zs. \& Laszlovszky, J. (2018). Research on landscape archaeology in the context of nomad towns. Hungarian Archaeology 7/2 [2018 Summer], 1524. http://files.archaeolingua.hu/2018NY/Upload/Khiland_E18NY.pdf_(Last accessed: 4 November 2020.)

Laszlovszky, J. \& Szilágyi, Zs. (2018). A Fehér Palota Mongóliában [The White Palace in Mongolia]. Várak, kastélyok, templomok 14/5 (2018 október), 36-39.

Laszlovszky, J. \& Szilágyi, Zs. (2019). Mongóliai elpusztult kolostorok nyomában [On destroyed monasteries in Mongolia]. Várak, kastélyok, templomok 15/3 (2019 június), 32-35.

Shimamura, I. (2014a). Ancestral spirits love mining sites. Shamanic activities around a copper-gold mining site in Mongolia. Inner Asia 16/2 (2014): 393-408. https://doi.org/10.1163/22105018-12340025

Shimamura, I. (2014b). The Roots Seekers: Shamainsm and Ethnicity among the Mongol Buryats. Yokohama: Shimpusha Publishing.

Szilágyi, Zs. (2016). Lingering nomad ideology in 21th-century Mongolia. Acta Ethnographica Hungarica 61 (2016), 197-211. http://dx.doi.org/10.1556/022.2016.61.1.9

Tanaka, K. (2002). Kokka wa kokka nashi de ikinokoru koto ga dekimasu ka? Buriyātomongoru no chishiki hito. [Can a Nation Survive without State? Intellectuals of Buryat Mongols]. In E. Kurocla, (ed.), Minzoku no undou to shido ushatachi [National Movements and Their Leaders] (pp. 74-95). Tokyo: Yamakawa Shuppan.

Tolnai, K., Erdenebold, Lkh., Harmath, A., Siklódi, Cs., Szilágyi, Zs. \& Laszlovszky, J. (2019). Landscape archaeological research around nomadic cities in East Mongolia - Results of the 2019 fieldwork of the KhiLand project. Hungarian Archaeology 8/2 [2019 Summer], 18-27. http://files.archaeolingua.hu/2019NY/ Upload/cikk_Laszlovszky_E.pdf (Last accessed: 4 November 2020.)

Zhukovskaya, N. (2009). Heritage versus Big Business: Lessons from the Yukos affair. Inner Asia 11/1 (2009), 157-167. https://doi.org/10.1163/000000009793066659 